\title{
Mycobacterium bovis Bacille Calmette-Guerin infection modulates GRK2/3 dependent cytokine secretion
}

\author{
Manisha Yadav ${ }^{1 *}$, D Nagarjuna', Rakesh Singh Dhanda² \\ From 2nd International Science Symposium on HIV and Infectious Diseases (HIV SCIENCE 2014) \\ Chennai, India. 30 January - 1 February 2014
}

\section{Background}

Mycobacterium tuberculosis has evolved highly specialized mechanisms to proliferate in the host during infection. In this process, the infection of alveolar epithelial cells is a necessary step for mycobacteria dissemination; however the mechanisms of mycobacterial epithelial interactions are incompletely understood. Previously, we characterized the role of epithelial G protein coupled receptors (GPCR) CXCR1 and CXCR2 during mycobacterial infection. However the role of GPCR kinases (GRK) 2/3 and GRK4-6 in response to mycobacterial infection has not been investigated.

\section{Methods}

The GPCR kinases expression (GRK2/3 and GRK4-6) after Mycobacterium infection was quantified by RT-PCR and Western blot analysis. Further, the secretion of cytokines IL- 8 and TNF- $\alpha$ was quantified in supernatants by ELISA.

\section{Results}

Mycobacterial infection in lung epithelial cells increased secretion of IL- 8 and decreased TNF- $\alpha$ upto 72 hours. Further, the infection in the epithelial cells was modulated by a combined up regulation of GPCR kinases (GRK) 2/3 genes and suppression of the GRK 4-6 gene expression. These results were confirmed at protein levels. In addition, the blocking of chemokine receptors decreased the inhibition of GRK 2/3 expression suggesting that mycobacteria manipulate epithelial responses by desensitizing the receptors and the cytokine secretion.

\footnotetext{
* Correspondence: myadav@acbr.du.ac.in

'Dr. B.R. Ambedkar Centre for Biomedical Research, University of Delhi, Delhi, India

Full list of author information is available at the end of the article
}

\section{Conclusions}

In conclusion, we have identified a role for GRK $2 / 3$ dependent cytokine secretion in the initial phase of mycobacterial infections in the lung epithelial cells.

\section{Authors' details \\ 'Dr. B.R. Ambedkar Centre for Biomedical Research, University of Delhi, Delhi, India. ${ }^{2}$ Department of Translational and Regenerative Medicine, Postgraduate} Institute of Medical Education and Research, Chandigarh, India.

Published: 27 May 2014

\section{doi:10.1186/1471-2334-14-S3-E20}

Cite this article as: Yadav et al:: Mycobacterium bovis Bacille Calmette-

Guerin infection modulates GRK2/3 dependent cytokine secretion. BMC

Infectious Diseases 2014 14(Suppl 3):E20.

\section{Submit your next manuscript to BioMed Central and take full advantage of: \\ - Convenient online submission \\ - Thorough peer review \\ - No space constraints or color figure charges \\ - Immediate publication on acceptance \\ - Inclusion in PubMed, CAS, Scopus and Google Scholar \\ - Research which is freely available for redistribution

